\title{
Ability of biofilm production and molecular analysis of spa and ica genes among clinical isolates of methicillin-resistant Staphylococcus
}

\section{aureus}

\author{
Mitra Omidi ${ }^{1}$, Farzaneh Firoozeh ${ }^{1,2,5^{*}} \mathbb{D}$, Mahmood Saffari ${ }^{1}$, Hossein Sedaghat ${ }^{1}$, Mohammad Zibaei ${ }^{3,4}$ \\ and Azad Khaledi ${ }^{1}$
}

\begin{abstract}
Objective: This study aimed to evaluate the phenotypic and genotypic characterization of biofilm formation and spa and ica genes among clinical isolates of methicillin-resistant Staphylococcus aureus.

Result: This cross-sectional study was performed on 146 Staphylococcus aureus isolates from hospitalized patients in Isfahan Province Hospitals. MRSA isolates were confirmed using disk diffusion test with oxacillin disk and amplification of mecA gene by PCR assays. Ability of biofilm production was evaluated targeting the icaA and icaD genes. Of 146 Staphylococcus aureus isolates, 24 (16.4\%) carried mecA genes and identified as MRSA strains. Strong ability of biofilm production was seen among 76.02\% (111/146) S. aureus isolates and 87.5\% (21/24) MRSA strains, respectively. Also, $75.0 \%$ (18/24) MRSA isolates carried icaA and icaD was not detected in these strains. Analysis of spa gene showed 70.83\% (17/24) MRSA strains were spa positive. From which 14 and 3 strains identified with one band (150, 270, 300, $360,400 \mathrm{bp}$ ) and two bands (150-300 bp), respectively. According to data obtained, the prevalence of MRSA isolates from Isfahan Province Hospitals is relatively high and a remarkable percentage of them show strong power in biofilm production. Also analysis of spa gene showed a fairly large diversity among MRSA strains.
\end{abstract}

Keywords: Staphylococcus aureus, MRSA, Biofilm, ica, femA, mecA, spa

\section{Introduction}

Staphylococcus aureus (S. aureus) is one of the most common causes of hospital- and community-acquired infections [1-3]. The development of hospital-adapted MRSA clones in the world, has really been problematic $[4,5]$. Resistance to methicillin in S. aureus strains is due to acquisition of mecA gene which encodes a changed penicillin-binding protein (PBP2a) [6-8].

\footnotetext{
*Correspondence: ffiroozeh@ut.ac.ir

${ }^{5}$ Department of Microbiology, School of Medicine, Alborz University

of Medical Sciences, Karaj 3149779453, IR, Iran

Full list of author information is available at the end of the article
}

Although mecA gene alone cannot be indicative of resistance to methicillin and existence of another ancillary gene especially femA (factors essential for methicillin-resistance) is also necessary for development of methicillin resistance [9]. The $S$. aureus protein A (SpA), as important virulence factor, is encoded by spa gene, which contain variable polymorphic $\mathrm{X}$ region [10]. The molecular characterization of $\mathrm{X}$ region of spa gene is documented as an exact method for typing of S. aureus strains [11].

The importance of biofilm production in pathogenesis of $S$. aureus and development of MDR strains has been documented $[12,13]$. Apart from other adhesion factors, a polysaccharide intercellular adhesion (PIA) 
which is encoded by ica operon is essential for biofilm formation in staphylococci $[13,14]$. The intercellular adhesion (ica) locus consists of icaADBC operon which contains four genes encoding the main proteins required for the generation of PIA. The first two genes including icaA and icaD perform principal role in the synthesis of exopolysaccharides [14]. The product of icaA gene is a transmembrane protein with $N$-acetylglucosaminyl transferases enzymatic activity which led to synthesis of the poly- $N$ acetyl glucosamine polymer [15]. It has been documented that, the product of the icaD gene, is essential for the most favorable enzymatic activity of the product of icaA gene $[15,16]$.

In this study methicillin-resistant Staphylococcus aureus strains were identified targeting mecA and $f e m A$ genes and the analysis of spa gene among MRSA strains was done. Also the ability of biofilm formation was evaluated using genes carried by ica locus.

\section{Main text \\ Materials and methods \\ Bacterial isolates}

In this cross-sectional study, $146 \mathrm{~S}$. aureus isolates were collected during June 2017 to September 2018 from hospitalized patients in Isfahan Province Hospitals. Identification of isolates as $S$. aureus strains was done by standard microbiological methods [17].

\section{Phenotypic and genotypic identification of MRSA strains}

For phenotypic identification of MRSA strains, susceptibility of isolates to cefoxitin $(30 \mu \mathrm{g})$ and oxacillin $(1 \mu \mathrm{g})$ disks (Mast, UK) were determined by disk diffusion method according to Clinical and Laboratory Standards Institute (CLSI) guidelines. The S. aureus strain COL and S. aureus ATCC 25923 were used as MRSA and methicillin-susceptible Staphylococcus aureus (MSSA) control strains respectively.

MRSA strains which had been identified phenotypically, confirmed by amplification of $m e c A$ and femA genes by PCR assays using specific primers $[9,19]$. Genomic DNA was extracted by phenol chloroform method. PCR of mecA gene was done to amplify a 268 bp amplicon and reaction conditions was as follows: 6 min at $97^{\circ} \mathrm{C}, 30$ cycles of $30 \mathrm{~s}$ at $92{ }^{\circ} \mathrm{C}, 30 \mathrm{~s}$ at $55{ }^{\circ} \mathrm{C}, 45 \mathrm{~s}$ at $72{ }^{\circ} \mathrm{C}$, and finally $10 \mathrm{~min}$ at $72{ }^{\circ} \mathrm{C}$ [20].

Also for amplification of $450 \mathrm{bp}$ amplicon of $f e m A$ gene the following PCR program was used: $94{ }^{\circ} \mathrm{C}$ for 5 min, 40 cycles of denaturation $\left(94{ }^{\circ} \mathrm{C}, 30 \mathrm{~s}\right)$, annealing $\left(55^{\circ} \mathrm{C}, 40 \mathrm{~s}\right)$ and primer extension $\left(72{ }^{\circ} \mathrm{C}, 50 \mathrm{~s}\right)$, with a final extension at $72{ }^{\circ} \mathrm{C}$ for $10 \mathrm{~min}$ [21].

\section{Antibiotic susceptibility testing}

According to the CLSI guidelines, resistance to antimicrobial agents was determined by disk diffusion method. The studied antibiotics were purchased from MAST company (Mast, UK) including: cefazolin, erythromycin, clindamycin, linezolid, trimethoprim sulfamethoxazole, vancomycin. The S. aureus strain ATCC 25923 was used as control. Vancomycin and oxacillin MICs of MRSA strains were determined using broth microdilution method and interpretation was done using susceptibility breakpoints according to the CLSI guidelines [18].

\section{Biofilm production assays}

Ability of biofilm production of all S. aureus isolates were determined by crystal violet staining assay [22]. As a negative control, uninoculated medium was used for determination of background OD. The average OD values were calculated for all tested strains and negative controls, and the cut-off OD value (ODc) was established. For interpretation of the results, strains were divided into the following groups: (I) $\mathrm{OD} \leq \mathrm{ODc}=$ no biofilm producer (0), (II), ODc $<$ OD $\leq(2 \times$ ODc $)=$ weak biofilm producer $(+$ or 1$)$, (III) $(2 \times$ ODc $)<$ OD $\leq(4 \times$ ODc $)=$ moderate biofilm producer $(++$ or 2$)$, (IV) $(4 \times \mathrm{ODc})<\mathrm{OD}=$ strong biofilm producer $(+++$ or 3$)$ [23].

\section{Detection of icaA and icaD genes}

The icaA and icaD genes were amplified in MRSA strains by PCR to detect 814 bp and $371 \mathrm{bp}$ amplicons respectively using primers reported in reference 24 . DNA amplification was carried out in a thermocycler (Eppendorf master cycler $^{\circledR}$, MA) with the following program: $94{ }^{\circ} \mathrm{C}, 5 \mathrm{~min}$, followed by 50 cycles of $\left(94{ }^{\circ} \mathrm{C}\right.$, $30 \mathrm{~s}, 59^{\circ} \mathrm{C}, 30 \mathrm{~s}$ and $72{ }^{\circ} \mathrm{C}, 30 \mathrm{~s}$ ) ending with $72{ }^{\circ} \mathrm{C}$ for $1 \mathrm{~min}$ [24]. After electrophoresis on $1 \%$ gel agarose the PCR products were visualized under UV transilluminator (Bio-Rad, UK).

\section{Molecular analysis of spa gene}

The variable polymorphic $\mathrm{X}$ region of the spa gene was amplified in MRSA strains and amplification reaction was according to previous studies [25].

\section{Statistical analysis}

Statistical analyses were done using SPSS software version 21 (SPSS, Inc.). Differences were considered by the Chi square $\left(\chi^{2}\right)$ test and $P$-values less than 0.05 was considered statistically significant.

\section{Results}

Of the 146 S. aureus isolates 64 (43.8\%) and 82 (56.2\%) isolates were recovered from males and females, 
respectively. The age of patients ranged from 4 months to 84 years with the mean age of 43.02 years. The clinical specimens included burn wound 56 (38.4\%), diabetic wound infection $5(3.4 \%)$, traumatic wounds 6 (4.1\%), eye infection 49 (33.6\%), urine $9(6.2 \%)$, blood 3 (2\%), brain abscess $5(3.4 \%)$, respiratory tract infections $11(7.5 \%)$, and other infections 2 (1.4\%) (Table 1).

Among total S. aureus isolates, 24 (16.4\%) identified as MRSA strains by disk diffusion method using cefoxitin and oxacillin disks, while the remaining 122 (83.6\%) strains were MSSA. All 24 identified MRSA strains showed to carry $m e c A$ and $f e m A$ genes.

The results of the antimicrobial sensitivity tests are represented in Table 2. Vancomycin resistance was not detected among the $S$. aureus isolates, although 3 (2.1\%) of isolates showed resistance to linezolid. Also $52(35.6 \%)$ of isolates identified as multidrug resistant (MDR) strains, which most of them were isolated from burn wounds and eye infections, respectively (Table 2). The results of phenotypic study of biofilm production, showed that 136 of 146 (93.1\%) S. aureus isolates was biofilm producer, from which, 111, 6 and 19 isolates identified as strong, moderate and weak biofilm producers respectively. Also 23/24 (95.8\%) MRSA strains identified as biofilm producer, from which $21(87.5 \%), 1(4.2 \%)$ and $1(4.2 \%)$ were strong, moderate and weak biofilm producers, respectively. The results of phenotypic study of biofilm production in MSSA strains were as follow: 113 out of 122 (92.6\%) MSSA isolates were biofilm producer, from which 90 (73.7\%), 5 (4.1\%) and 18 (14.8) identified with strong, moderate and weak biofilm production ability respectively.

Molecular study of icaA and icaD genes among 24 MRSA strains revealed that 18 isolates carried icaA gene while icaD gene was not detected in all MRSA strains, and 6 isolates did not carry any of these two genes. Seventeen out Of $18 \mathrm{icaA}$ positive MRSA strains, had been identified as strong biofilm producers by phenotypic method, whilst 4/6 MRSA strains that did not carry ica genes, were strong biofilm producer. Analysis of spa gene among 24 MRSA isolates showed that 17/24 MRSA strains carried spa genes of different types (Table 3). From which 14 spa positive MRSA strains identified with one band of different length including 150, 270, 300, 360, $400 \mathrm{bp}$ and 3 spa positive MRSA strains founded to carry double bands of spa genes with the length of 150-300 bp. Majority of spa positive MRSA strains had one band with the length of $300 \mathrm{bp}$.

The statistical analyses showed significant correlation between MRSA isolation and MDR phenotype. Also a clear association was seen between the methicillin resistance and hospital where the clinical specimen has been isolated $\left(P^{<} 0.05\right)$.
Table 1 Comparison between MRSA and MSSA isolates regarding characteristics of patients, biofilm production ability and antibiotic resistance

\begin{tabular}{|c|c|c|c|}
\hline Factors & $\mathrm{MRSA}^{\mathrm{a}}, \mathrm{N}(\%)$ & $\mathrm{MSSA}^{\mathbf{b}}, \mathrm{N}(\%)$ & $P$-value ${ }^{c}$ \\
\hline \multicolumn{4}{|l|}{ Age } \\
\hline $0-25$ & $3(12.5)$ & $33(27.0)$ & \multirow[t]{3}{*}{0.33} \\
\hline $26-50$ & $9(37.5)$ & $35(28.7)$ & \\
\hline $51-84$ & $12(50.0)$ & $54(44.3)$ & \\
\hline \multicolumn{4}{|l|}{ Sex } \\
\hline Male & $13(54.2)$ & $51(41.8)$ & \multirow[t]{2}{*}{0.08} \\
\hline Female & $11(45.8)$ & $71(58.2)$ & \\
\hline \multicolumn{4}{|l|}{ Clinical specimens } \\
\hline Burn wound & $15(62.4)$ & $41(33.6)$ & \multirow[t]{9}{*}{0.12} \\
\hline Diabetic wound & $0(0.0)$ & $5(4.1)$ & \\
\hline Traumatic wounds & $0(0.0)$ & $6(4.9)$ & \\
\hline Eye & $6(25.0)$ & $43(35.2)$ & \\
\hline Urine & $0(0.0)$ & $9(7.4)$ & \\
\hline Blood & $1(4.2)$ & $2(1.7)$ & \\
\hline Brain abscess & $1(4.2)$ & $4(3.3)$ & \\
\hline Respiratory tract & $1(4.2)$ & $10(8.2)$ & \\
\hline Other & - & $2(1.6)$ & \\
\hline \multicolumn{4}{|l|}{ Hospitals } \\
\hline Kashan & & & \multirow[t]{6}{*}{0.001} \\
\hline Shahid Beheshti & $3(12.5)$ & $49(40.2)$ & \\
\hline \multicolumn{3}{|l|}{ Isfahan } & \\
\hline $\begin{array}{l}\text { Imam Musa Kazem } \\
\text { (Burns hospital) }\end{array}$ & $15(62.5)$ & $41(33.6)$ & \\
\hline Al-Zahra & $2(8.3)$ & $29(23.7)$ & \\
\hline Amin & $4(16.7)$ & $3(2.5)$ & \\
\hline \multicolumn{4}{|l|}{ Wards } \\
\hline Burns & $15(62.5)$ & $41(33.6)$ & \multirow[t]{5}{*}{0.09} \\
\hline Infectious diseases & - & $14(11.5)$ & \\
\hline Emergency & $7(29.2)$ & $47(38.5)$ & \\
\hline$I C U^{d}$ & $2(8.3)$ & $11(9.0)$ & \\
\hline Outpatients & - & $9(7.4)$ & \\
\hline \multicolumn{4}{|l|}{ Biofilm production ability } \\
\hline Strong & $21(87.5)$ & $90(73.7)$ & \multirow[t]{4}{*}{0.43} \\
\hline Moderate & $1(4.2)$ & $5(4.1)$ & \\
\hline Weak & $1(4.2)$ & $18(14.8)$ & \\
\hline Non-biofilm producers & $1(4.2)$ & $9(7.4)$ & \\
\hline \multicolumn{4}{|l|}{ Antibiotic resistance } \\
\hline $\mathrm{MDR}^{\mathrm{e}}$ & $20(83.3)$ & $32(26.2)$ & \multirow[t]{2}{*}{0.001} \\
\hline Non-MDR & $4(16.7)$ & $90(73.8)$ & \\
\hline Total & 24 & 122 & \\
\hline
\end{tabular}

\footnotetext{
a Methicillin-resistant Staphylococcus aureus

b Methicillin-susceptible Staphylococcus aureus

c $P<0.05$ is significant

$d$ Intensive care unit

e Multiple-drug resistance
} 
Table 2 The antimicrobial sensitivity tests of MSSA and MRSA isolates by disk diffusion method

\begin{tabular}{|c|c|c|c|c|c|c|}
\hline \multirow[t]{2}{*}{ Antibiotic } & \multicolumn{3}{|l|}{ MSSA $(n=122)$} & \multicolumn{3}{|l|}{ MRSA $(n=24)$} \\
\hline & Susceptible N (\%) & Intermediate N (\%) & Resistant N (\%) & Susceptible N (\%) & $\begin{array}{l}\text { Intermediate } \\
\mathrm{N}(\%)\end{array}$ & Resistant N (\%) \\
\hline Erythromycin & $62(50.8)$ & $32(26.2)$ & $28(23.0)$ & $5(20.8)$ & $2(8.4)$ & $17(70.8)$ \\
\hline Clindamycin & $100(82.0)$ & $14(11.5)$ & $8(6.5)$ & $6(25.0)$ & $4(16.7)$ & $14(58.3)$ \\
\hline Cefoxitin & $122(83.6)$ & $0(0.0)$ & $0(0.0)$ & $0(0.0)$ & $0(0.0)$ & $24(16.4)$ \\
\hline Cefazolin & $119(97.5)$ & $2(1.7)$ & $1(0.8)$ & $11(45.8)$ & $0(0.0)$ & $13(54.2)$ \\
\hline Linezolid & $120(98.4)$ & $0(0.0)$ & $2(1.6)$ & $23(95.8)$ & $0(0.0)$ & $1(4.2)$ \\
\hline $\begin{array}{l}\text { Trimethoprim/sul- } \\
\text { famethoxazole }\end{array}$ & $112(91.8)$ & $4(3.3)$ & $6(4.9)$ & $16(66.7)$ & $0(0.0)$ & $8(33.3)$ \\
\hline
\end{tabular}

Table 3 Analysis of spa gene in MRSA isolates regarding to hospital and clinical specimens

\begin{tabular}{|c|c|c|c|c|c|c|}
\hline spa band & Size (bp) & Number (\%) & Sex & Clinical specimens & Hospital & Wards \\
\hline \multicolumn{7}{|l|}{ No band } \\
\hline & - & $7(29.1)$ & Male & Burn wound & IMKa Burns hospital & Burns \\
\hline & & & Male & Burn wound & IMK Burns hospital & Burns \\
\hline & & & Male & Burn wound & IMK Burns hospital & Burns \\
\hline & & & Female & Eye & Amin & Emergency \\
\hline & & & Female & Eye & Amin & Emergency \\
\hline & & & Female & Eye & Amin & Emergency \\
\hline & & & Female & Brain abscess & Al-Zahra & $\mathrm{ICU}$ \\
\hline \multicolumn{7}{|l|}{ One band } \\
\hline & 150 & $3(12.5)$ & Male & Burn wound & IMK Burns hospital & Burns \\
\hline & & & Male & Burn wound & IMK Burns hospital & Burns \\
\hline & & & Female & Burn wound & IMK Burns hospital & Burns \\
\hline & 270 & $4(16.7)$ & Male & Burn wound & IMK Burns hospital & Burns \\
\hline & & & Male & Burn wound & IMK Burns hospital & Burns \\
\hline & & & Male & Burn wound & IMK Burns hospital & Burns \\
\hline & & & Female & Eye & Amin & Emergency \\
\hline & 300 & $4(16.7)$ & Male & Blood & Shahid Beheshti & Emergency \\
\hline & & & Male & Eye & Shahid Beheshti & Emergency \\
\hline & & & Male & Burn wound & IMK Burns hospital & Burns \\
\hline & & & Female & Respiratory tract & Al-Zahra & $\mathrm{ICU}$ \\
\hline & 360 & $2(8.3)$ & Female & Eye & Shahid Beheshti & Emergency \\
\hline & & & Female & Burn wound & IMK Burns hospital & Burns \\
\hline & 400 & -4.2 & Female & Burn wound & IMK Burns hospital & Burns \\
\hline \multicolumn{7}{|l|}{ Two band } \\
\hline & $150-300$ & $3(12.5)$ & Male & Burn wound & IMK Burns hospital & Burns \\
\hline & & & Male & Burn wound & IMK Burns hospital & Burns \\
\hline & & & Female & Burn wound & IMK Burns hospital & Burns \\
\hline Total & $24(100)$ & & & & & \\
\hline
\end{tabular}

a Imam Musa Kazem Burns hospital

\section{Discussion}

Our data revealed that of all S. aureus isolates, $16.4 \%$ identified as MRSA strains by both phenotypic and genotypic methods. The prevalence of MRSA strains varies in different geographic regions, as in a review study has been shown that the prevalence of MRSA infection ranges from 13 to $74.0 \%$ in different parts of the world [26]. In Iran, a meta-analysis study has been reported that prevalence of MRSA infections in Mazandaran, Isfahan, Markazi, Golestan and Kerman Provinces is about 
20.5 percent $[27,28]$. Despite there was no significant relationship between sex, clinical specimens and resistance to methicillin $(P>0.05)$, most MRSA isolates were recovered from men over 50 years old with burn wound infections. These results may be due to the fact that men are more likely to be burned because of their jobs; also antibiotic resistance is high in the bacterial strains that cause burn infections. Linezolid is a new class of antibiotics that are introduced for treatment of infections due to MRSA [29]. Linezolid-resistant Staphylococcus aureus (LRSA) is still very uncommon [30]. In the present study we have reported the emergence of LRSA strains in our region for the first time. The published reports of infections due to LRSA strains between the years 2001 and 2011 in different parts of world indicate a prevalence of $0.05 \%$ [31]. In studies conducted in different geographic areas of Iran, the LRSA strains have not been documented, except studies conducted in Tabriz and Mashhad [32]. Isolation of LRSA strains from important clinical specimens such as burn wound infection and diabetic foot ulcer, can be a serious threat due to the spread of these resistant strains in the hospitals. Detailed studies based on molecular typing of strains can be very beneficial in this field. The ability of $S$. aureus strains to produce biofilm due to the durability and antibiotic resistance is among the most important virulence factors [33]. Majority of our studied $S$. aureus strains had the ability to produce strong biofilm. In comparison to other studies in Iran, the ability and power of biofilm production in our strains was much higher; however, the methods used in studies also contribute to this difference [34, 35]. Since the most of our $S$. aureus strains have been isolated from hospitalized patients and clinical samples such as burn wounds, this high power of biofilm production is very important and requires more detailed studies in this regard. Although different genes are involved in biofilm production, but in contradiction to other studies, icaD gene was not detected in our biofilm producer MRSA strains and icaA gene was the gene specifically detected in our MRSA strains with the ability of strong biofilm production [36]. The interesting result in this context was that $4 / 6$ MRSA strains that did not carry ica genes, were strong biofilm producers. This indicates that genes other than ica may have been involved in biofilm formation in these strains.

The analysis of spa genes showed that the length of detected genes in the present study was shorter than the length of the spa genes identified by Shakeri et al. in north of Iran [37]. This can be related to the differences in the pattern of distribution of spa types across different geographic regions. Using the sequencing method and determining the exact spa types of $S$. aureus strains can be helpful in proving this claim. In the current study, 6 different patterns of spa gene are detected. Findings of an investigation have been reported 5 different patterns of this gene among patients with staphylococcal infections [10].

\section{Conclusion}

According to data obtained, the prevalence of MRSA strains in S. aureus isolates from Isfahan Province Hospitals is relatively high and a remarkable percentage of them show strong power in biofilm production. Also analysis of spa gene showed a fairly large diversity among MRSA strains isolated from different hospitals, although more detailed studies using sequencing and accurate typing methods such as MLST can prove this claim.

\section{Limitations}

- The most important limitation of the present study is that the molecular study of genes involved in biofilm production has been performed only in MRSA strains and the mentioned studies have not been performed on MSSA strains.

\section{Abbreviations}

MRSA: methicillin-resistant Staphylococcus aureus; PBP2a: penicillin-binding protein; MSCRAMMs: microbial surface components recognizing adhesive matrix molecules; SpA: S. aureus protein A; MDR: multi-drug resistant; PIA: polysaccharide intercellular adhesion; TSB: trypticase soy broth; CLSI: Clinical and Laboratory Standards Institute; MSSA: methicillin-susceptible Staphylococcus aureus; PCR: polymerase chain reaction; PBS: phosphate buffered saline; OD: optical densities; LRSA: Linezolid-resistant Staphylococcus aureus; MLST: multilocus sequence typing.

\section{Acknowledgements}

The technical assistance of the staff of Microbiology Laboratory, of the Department of Microbiology and Immunology, School of Medicine, Kashan University of Medical Sciences are gratefully acknowledged. The results described in this paper formed part of an M.Sc. student thesis.

\section{Authors' contributions}

All authors'listed in this research article have been involved and contribute for this study. MO and FF conceptualized and designed the study. MO, FF, MS and HS performed the lab work. FF, MS, MZ and AK analyzed the dataset. Manuscript was prepared by MO, FF, MZ and AK. All authors read and approved the final manuscript.

\section{Funding}

No funding was received for this research study.

\section{Availability of data and materials}

The datasets used and analyzed during the current study are available from the corresponding author on reasonable request.

\section{Ethics approval and consent to participate}

The purpose and procedures of the study were explained to all participants, and a written informed consent was obtained from all of them. The study was approved by the ethical clearance committees of the Kashan University of Medical Sciences (IR.KAUMS.REC.1396.003). 


\section{Consent to publication \\ Not applicable.}

\section{Competing interests}

The authors declare that they have no competing interests.

\begin{abstract}
Author details
${ }^{1}$ Department of Microbiology and Immunology, School of Medicine, Kashan University of Medical Sciences, Kashan, Iran. ${ }^{2}$ Dietary Supplements and Probiotic Research Center, Alborz University of Medical Sciences, Karaj, Iran. ${ }^{3}$ Department of Parasitology and Mycology, School of Medicine, Alborz University of Medical Sciences, Karaj, Iran. ${ }^{4}$ Evidence-Based Phytotherapy and Complementary Medicine Research Center, Alborz University of Medical Sciences, Karaj, Iran. ${ }^{5}$ Department of Microbiology, School of Medicine, Alborz University of Medical Sciences, Karaj 3149779453, IR, Iran.
\end{abstract}

Received: 30 September 2019 Accepted: 2 January 2020 Published online: 07 January 2020

\section{References}

1. Bishara J, Goldberg E, Leibovici L, Samra Z, Shaked H, Mansur N, Paul M. Healthcare-associated vs. hospital-acquired Staphylococcus aureus bacteremia. Int J Infect Dis. 2012;16:e457-63.

2. Boswihi SS, Udo EE. Methicillin-resistant Staphylococcus aureus: an update on the epidemiology, treatment options and infection control. J Curr Med Res Pract. 2018;8:18-24.

3. García-Álvarez L, Holden MT, Lindsay H, Webb CR, Brown DF, Curran MD, Walpole E, Brooks K, Pickard DJ, Teale C, Parkhill J, Bentley SD, Edwards GF, Girvan EK, Kearns AM, Pichon B, Hill RL, Larsen AR, Skov RL, Peacock SJ, Maskell DJ, Holmes MA. Methicillin-resistant Staphylococcus aureus with a novel mecA homologue in human and bovine populations in the UK and Denmark: a descriptive study. Lancet Infect Dis. 2011;11:595-603.

4. Udo EE. Community-acquired methicillin-resistant Staphylococcus aureus: the new face of an old foe? Med Princ Pract. 2013;22:20-9.

5. Strommenger B, Braulke C, Heuck D, Schmidt C, Pasemann B, Nübel U, Witte W. spa typing of Staphylococcus aureus as a frontline tool in epidemiological typing. J Clin Microbiol. 2008;46:574-81.

6. Deurenberg RH, Vink C, Kalenic S, Friedrich AW, Bruggeman CA, Stobberingh EE. The molecular evolution of methicillin-resistant Staphylococcus aureus. Clin Microbiol Infect. 2007;13:222-35.

7. Kluytmans-Vandenbergh MF, Kluytmans JA. Community-acquired methicillin-resistant Staphylococcus aureus: current perspectives. Clin Microbiol Infect. 2006;12:9-15.

8. Bressler AM, Williams T, Culler EE, Zhu W, Lonsway D, Patel JB, Nolte FS Correlation of penicillin binding protein 2a detection with oxacillin resistance in Staphylococcus aureus and discovery of a novel penicillin binding protein 2a mutation. J Clin Microbiol. 2005;43:4541-4.

9. Chikkala R, George NO, Ratnakar KS, Iyer RN, Sritharan V. Heterogeneity in femA in the Indian isolates of Staphylococcus aureus limits its usefulness as a species specific marker. Adv Infect Dis. 2012;2:82-8.

10. Afrough P, Pourmand MR, Sarajian AA, Saki M, Saremy S. Molecular investigation of Staphylococcus aureus, coa and spa genes in Ahvaz Hospitals, staff nose compared with patients clinical samples. Jundishapur J Microbiol. 2013;6:e5377.

11. Ruppitsch W, Indra A, Stöger A, Mayer B, Stadlbauer S, Wewalka G, Allerberger F. Classifying spa types in complexes improves interpretation of typing results for methicillin resistant Staphylococcus aureus. J Clin Microbiol. 2006;44:2442-8.

12. Namvar AE, Asghari B, Ezzatifar F, Azizi G, Lari AR. Detection of the intercellular adhesion gene cluster (ica) in clinical Staphylococcus aureus isolates. GMS Hyg Infect Control. 2013;8:Doc03.

13. O'Gara JP. ica and beyond: biofilm mechanisms and regulation in Staphylococcus epidermidis and Staphylococcus aureus. FEMS Microbiol Lett. 2007;270:179-88.

14. Götz F. Staphylococcus and biofilms. Mol Microbiol. 2002;43:1367-78.

15. Arciola CR, Campoccia D, Ravaioli S, Montanaro L. Polysaccharide intercellular adhesin in biofilm: structural and regulatory aspects. Front Cell Infect Microbiol. 2015;5:7
16. Rohde H, Frankenberger S, Zähringer U, Mack D. Structure, function and contribution of polysaccharide intercellular adhesin (PIA) to Staphylococcus epidermidis biofilm formation and pathogenesis of biomaterial-associated infections. Eur J Cell Biol. 2010;89:103-11.

17. Mahon CR, Lehman DC, Manuselis G. Textbook of diagnostic microbiology. 5th ed. Washington DC: Saunders; 2015.

18. Amiri A, Firoozeh F, Moniri R, Zibaei M. Prevalence of CTX-M-Type and PER extended-spectrum $\beta$-lactamases among Klebsiella spp. isolated from clinical specimens in the teaching hospital of Kashan, Iran. Iran Red Crescent Med J. 2016;18:e22260.

19. Ito T, Kuwahara-Arai K, Katayama Y, Uehara Y, Han X, Kondo Y, Hiramatsu K. Staphylococcal cassette chromosome mec (SCCmec) analysis of MRSA. Methods Mol Biol. 2014;1085:131-48.

20. Pourmand MR, Hassanzadeh S, Mashhadi R, Askari E. Comparison of four diagnostic methods for detection of methicillin resistant Staphylococcus aureus. Iran J Microbiol. 2014;6:341-4.

21. Jukes L, Mikhail J, Bome-Mannathoko N, Hadfield SJ, Harris LG, El-Bouri K, Davies AP, Mack D. Rapid differentiation of Staphylococcus aureus, Staphylococcus epidermidis and other coagulase-negative staphylococci and meticillin susceptibility testing directly from growth-positive blood cultures by multiplex real-time PCR. J Med Microbiol. 2010;59:1456-61.

22. Torlak E, Korkut E, Uncu AT, Sener Y. Biofilm formation by Staphylococcus aureus isolates from a dental clinic in Konya, Turkey. J Infect Public Health. 2017;10:809-13.

23. Stepanović S, Vuković D, Hola V, Di Bonaventura G, Djukić S, Cirković I, Ruzicka F. Quantification of biofilm in microtiter plates: overview of testing conditions and practical recommendations for assessment of biofilm production by staphylococci. APMIS. 2007;115:891-9.

24. Diemond-Hernández B, Solórzano-Santos F, Leaños-Miranda B, PeregrinoBejarano L, Miranda-Novales G. Production of icaADBC-encoded polysaccharide intercellular adhesin and therapeutic failure in pediatric patients with Staphylococcal device-related infections. BMC Infect Dis. 2010;10:68.

25. Bhati T, Nathawat P, Sharma SK, Yadav R, Bishnoi J, Kataria AK. Polymorphism in spa gene of Staphylococcus aureus from bovine subclinical mastitis. Vet World. 2016;9:421-4.

26. Hassoun A, Linden PK, Friedman B. Incidence, prevalence, and management of MRSA bacteremia across patient populations-a review of recent developments in MRSA management and treatment. Crit Care. 2017;21:211.

27. Dadashi M, Nasiri MJ, Fallah F, Owlia P, Hajikhani B, Emaneini M, Mirpour M. Methicillin-resistant Staphylococcus aureus (MRSA) in Iran: a systematic review and meta-analysis. J Glob Antimicrob Resist. 2018;12:96-103.

28. Askari E, Soleymani F, Arianpoor A, Tabatabai SM, Amini A, Naderinasab M. Epidemiology of mecA-methicillin resistant Staphylococcus aureus (MRSA) in Iran: a systematic review and meta-analysis. Iran J Basic Med Sci. 2012;15:1010-9.

29. Watkins RR, Lemonovich TL, File TM Jr. An evidence-based review of linezolid for the treatment of methicillin-resistant Staphylococcus aureus (MRSA): place in therapy. Core Evid. 2012;7:131-43.

30. Endimiani A, Blackford M, Dasenbrook EC, Reed MD, Bajaksouszian S, Hujer AM, Rudin SD, Hujer KM, Perreten V, Rice LB, Jacobs MR, Konstan MW, Bonomo RA. Emergence of linezolid-resistant Staphylococcus aureus after prolonged treatment of cystic fibrosis patients in Cleveland, Ohio. Antimicrob Agents Chemother. 2011;55:1684-92.

31. Gu B, Kelesidis T, Tsiodras S, Hindler J, Humphries RM. The emerging problem of linezolid-resistant Staphylococcus. J Antimicrob Chemother. 2013:68:4-11.

32. Shirvani F, Sannai Dashti A, Seifi K. Staphylococcus and linezolid resistance in Iran. Arch Pediatr Infect Dis. 2018;6:e12236.

33. McCarthy H, Rudkin JK, Black NS, Gallagher L, O'Neill E, O'Gara JP. Methicillin resistance and the biofilm phenotype in Staphylococcus aureus. Front Cell Infect Microbiol. 2015;5:1.

34. Bimanand L, Taherikalani M, Jalilian FA, Sadeghifard N, Ghafourian S, Mahdavi Z, Mohamadi S, Sayehmiri K, Hematian A, Pakzad I. Association between biofilm production, adhesion genes and drugs resistance in different SCCmec types of methicillin resistant Staphylococcus aureus strains isolated from several major hospitals of Iran. Iran J Basic Med Sci. 2018:21:400-3.

35. Yousefi M, Pourmand MR, Fallah F, Hashemi A, Mashhadi R, Nazari-Alam A. Characterization of Staphylococcus aureus biofilm formation in urinary tract infection. Iran J Public Health. 2016:45:485-93. 
36. Serray B, Oufrid S, Hannaoui I, Bourjilate F, Soraa N, Mliji M, Sobh M, Hammoumi A, Timinouni M, El Azhari M. Genes encoding adhesion factors and biofilm formation in methicillin-resistant Staphylococcus aureus in Morocco. J Infect Dev Ctries. 2016;10:863-9.

37. Shakeri F, Shojai A, Golalipour M, Rahimi Alang S, Vaez H, Ghaemi EA. Spa diversity among MRSA and MSSA strains of Staphylococcus aureus in north of Iran. Int J Microbiol. 2010;2010:351397.

\section{Publisher's Note}

Springer Nature remains neutral with regard to jurisdictional claims in published maps and institutional affiliations.
Ready to submit your research? Choose BMC and benefit from:

- fast, convenient online submission

- thorough peer review by experienced researchers in your field

- rapid publication on acceptance

- support for research data, including large and complex data types

- gold Open Access which fosters wider collaboration and increased citations

- maximum visibility for your research: over $100 \mathrm{M}$ website views per year

At BMC, research is always in progress.

Learn more biomedcentral.com/submissions 